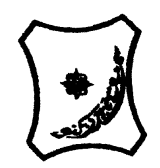

Bayero Journal of Pure and Applied Sciences, 14(1):207 - 213

Received: January, 2021

Accepted: March, 2021

ISSN $2006-6996$

\title{
ASSESSMENT OF SELECTED HEAVY METALS CONCENTRATIONS IN MAIRUA RESERVOIR, FUNTUA, KATSINA STATE, NIGERIA FOR FISHING PURPOSES
}

Karkarna,M. Z. and Dabo, Z. M.

Department of Environmental Management, Bayero University, Kano

Authors email: mzkarkarna@gmail.com and zmdabo@yahoo.com

ABSTRACT

An assessment of selected heavy metal concentrations for fishing purposes was conducted at Mairua Reservoir, Funtua, Katsina State, Nigeria. This study aimed at assessing the selected heavy metal concentrations to enable the efficient management and sustainable use of the reservoir. Fishing is the major activity of the dwellers throughout the year, but there is less attention in considering the water quality in the reservoir. Eating fish harvested from polluted aquatic habitats could endanger the health of the consumer. As such, there is the need of this research now if not continuously. Water samples were taken in five sampling points and the procedural plan was the monthly sampling of the water from February-April and June-August 2020. The heavy metals include Zinc (Zn), Iron (Fe), Nickel (Ni), Manganese (Mn), Cadmium (Cd) and Lead $(\mathrm{Pb})$. Laboratory procedures include sample digestions in preparation for spectrophotometric analysis using Atomic Absorption Spectrometer (AAS). Data were analysed using Analysis of Variance (ANOVA) and independent $t$-test and related with $F A O$ standard for fishing. The finding shows that most of the parameters like $\mathrm{Cd}, \mathrm{Zn}$ and $\mathrm{Pb}$ are more in concentration at SPIII (downstream), i.e. the outlet of the water in the reservoir. It can also be seen that two parameters Fe and Ni are more concentrated at SPIV (middle towards east) and only Mn is higher at SPI (upstream). Furthermore, the analysis of variance revealed no significant difference $(p>0.05)$ in the values of all the parameters across the five sampled collection points. The results of this study show that with the exception of cadmium (Cd) and lead (Pb), the heavy metal concentrations in water did not exceed FAO (2006) standards. However, Cd and Pb exceeded the FAO standard. The level of heavy metal concentrations was compared based on seasons (wet and dry) using independent $t$-test at the 0.05 level of significance. The result shows no significant difference at 0.05 between the wet and dry season values of Fe (P value $0.106), C d(P$ value 0.614), Zn (P value 0.700), Mn (P value 0.950), and Ni (P value $0.937)$.Study on $\mathrm{Pb}$ concentrations revealed that the metal was affected by seasonal variation ( $P$ value 0.047). Dumping waste very close to the reservoir should be discouraged. Farmers around the reservoir should be enlightened on the negative effects of their activities into the body of the water. More studies should be carried out on physico-chemical, microbial and other heavy metal concentrations in order to provide baseline information on the ecological status of the reservoir. In line with the finding, it is recommended that for effective fishing activities in the reservoir, the use of agrochemicals and dumping municipal waste very close to the reservoir, which could be the possible sources of $\mathrm{Cd}$ and $\mathrm{Pb}$, should be discouraged.

Key Words: Rservoir, Water Quality, Fishing, Mairua, Katsina

\section{INTRODUCTION}

Water is an abundant chemical substance composed of hydrogen and oxygen in a ratio $2: 1$, which is essential for the survival of all known forms of life. It is a very wonderful solvent on earth that supports plant and animal lives at various capacities (Tasi'u and Dabo, 2017). Most of the water in use is in liquid form, but it also exists in both solid and gaseous states. Spatially, it covers about $75 \%$ of the earth's surface most of which is in the oceans. Ground water constitutes $1.6 \%$ and $0.001 \%$ in the atmosphere as vapor, clouds, glacier and polar ice caps $(2.4 \%)$ and with land surface waters such as rivers, lakes and ponds, making up $0.6 \%$ (American Geophysical Union (AGU), 1995 and Nsi, 2007). 
BAJOPAS Volume 14 Number 1,June, 2021

Water is a finite and scarce resource due to increased demand for a growing population, world industrialization and other agricultural developments (Obadaki and Ari, 2014). Metals, such as copper and zinc, can leach into river water from mining industries and have been found to affect the fish population when present in water even at low doses (Saei-Dehkordi and Fallah, 2011).

A very small amount of the earth's water is contained within biological bodies and manufactured products. Heavy metal concentrations in fish may vary according to the surrounding environment (Sen et al., 2011), depending on environmental factors, such as the geology of the area, mean annual rainfall, drainage and average temperature. Armah et al. (2010) in a study of the anthropogenic sources of heavy metals in water surface in water in Ghana identified that $\mathrm{Pb}$ derives from water carrying drainage from mine machinery maintenance yards. Heavy Metals in aquatic environments have become a matter of great concern over the last few decades not only because of the threat to the quality of water but also the hazards posed to human health on the consumption of fishes (Tanee et al, 2013). These impacts are no doubt life threatening. As a result, the World Health Organization (2011) observed rightly that the contamination of the environment is not only a pollution issue but also a rising public health matter. This observation brings to the fore the necessity of assessing the contaminants in aquatic media.

Recent studies have revealed heavy metal concentrations in humans arising from fish consumption. Such studies have shown that in the world today, there is a spate of the occurrence of heavy metals in humans at higher concentrations, arising from the consumption of contaminated fish. For instance, Lye, et al. (2013) revealed the occurrence of total mercury in the blood of Canadians 6-79 years of age at increasing concentrations commensurate with total fish and shell fish consumption. Fishing is regarded as one of the major activities in the area, of which Mairua Reservoir is been utilized as the major fishing ground. Little was known about the water quality for effective and sustainable fish stocking like in other reservoirs within and outside Nigeria. These among other issues are the major reasons why the research was conducted in which the major objectives to assess the heavy metal concentrations of Mairua Reservoir to check it suitability for fishing purposes.

\section{Study Area}

Mairua Reservoir lies between latitude $11^{0} 34^{\prime} \mathrm{O}^{\prime \prime} \mathrm{N}$ to latitude $11^{0} 36^{\prime} \mathrm{O}^{\prime \prime} \mathrm{N}$ of the equator and longitude $75^{\circ} 14^{\prime} O^{\prime \prime} \mathrm{E}$ to longitude $7^{\circ} 16^{\prime} \mathrm{O}^{\prime \prime} \mathrm{E}$ of Greenwich Meridian (Figure 1) The overall mean temperature across the five sampling points of the reservoir was found to be $26.12^{\circ} \mathrm{C}$ and that of pH was $7.29 \mathrm{mgL}$ (Dabo, 2020). It is located in Funtua Local Government Area of Katsina State, North West Nigeria. Funtua is bordered by Faskari Local Government Area (LGA) to the north, Bakori LGA to the north-east, Danja LGA to the east, Giwa LGA (Kaduna State) to the south and Dandume LGA to the west (Katsina Wikipedia 2003). The hydrological nature of Funtua town consists of reservoirs, such as Mairua and Gwaigwaye, which are predominantly used for fishing and irrigation farming. The dominant method of fishing adopted is the use of a trawl and net. In some instances, the drag net is also used. The study area is well drained by a network of rivers and streams (Babsal, 1998). The area falls under the Northern-Guinea Savannah Zone, with a vegetation consisting of broad-leaved species with tall tussock grasses of guinea affinities mixed up with fine-leaved species of thorny trees with continuous short and feathery grass cover(Onamade, 2014). According to the 2006 population figure estimates, Funtua LGA had a population of 255,751 people (National Population Commission, 2006). Considering an increment of $3.5 \%$ annually from 2007 to 2019 it had a population figure estimated at 399890 people. The wet season starts in May and ends in early October and dry seasons last longer from November to April with total rainfall varying from 600-90QMM (Quintile Mapping for each Month) annually and a mean annual temperature of about $25^{\circ} \mathrm{C}$. The area is characterized by constant low relative humidity $(50 \%)$ and ashorter raining season. 


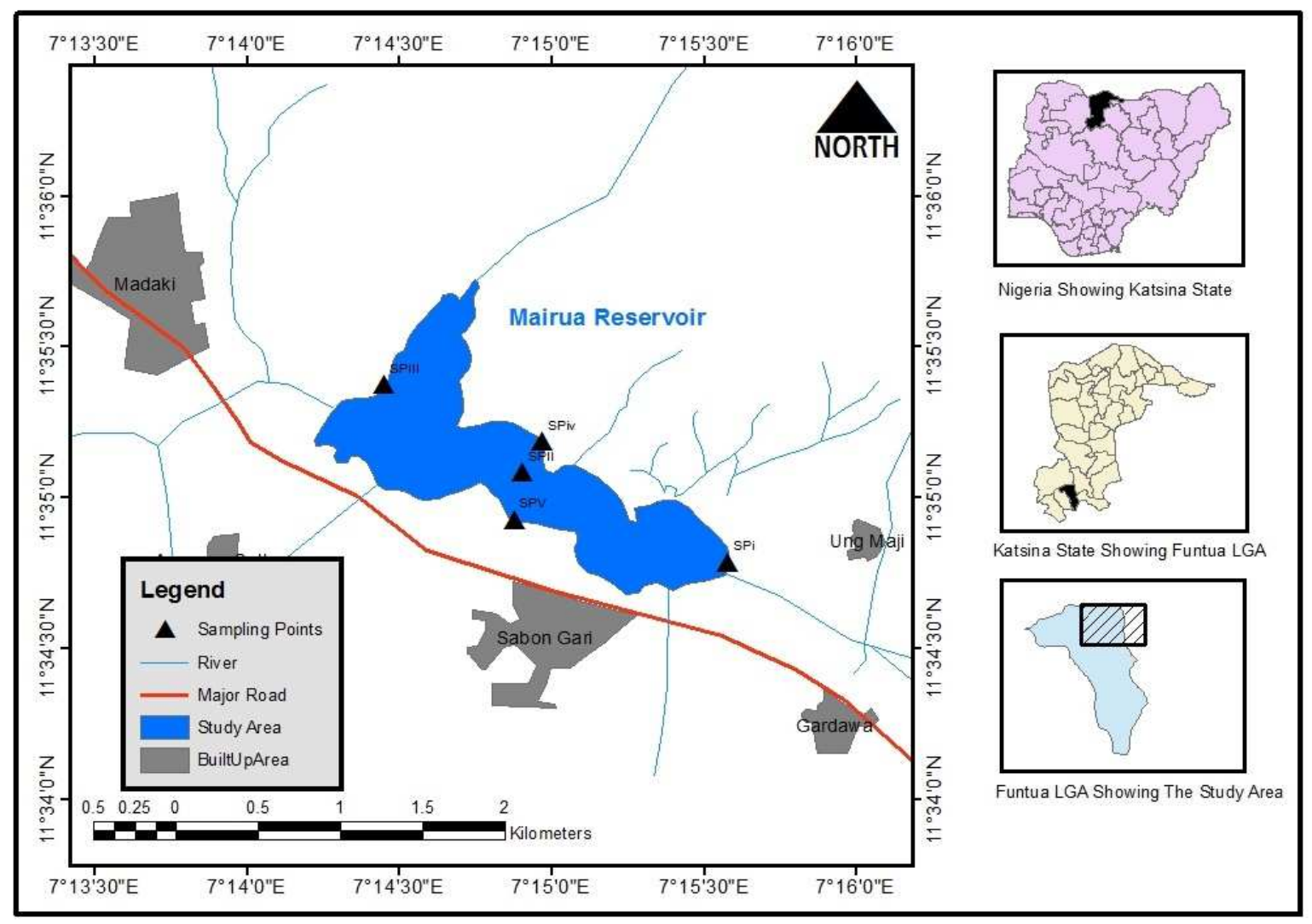

Figure 1: Mairua Reservoir and Sampling Points, Katsina State

Source: Cartography Lab. Department of Geography, Bayero University, Kano (2020)

\section{MATERIALS AND METHODS \\ Methods of Data Collection \\ Water Sampling Points Selections}

The procedural plan was the monthly sampling of water from February-April and June-August 2020 (three months each during the dry and wet seasons). The water samples were collected in the morning $(6: 00 \mathrm{am}$ to 7:00am) in five strata: The first stratum was labeled as Sampling Point I (SPI) and was selected from upstream (or inlet) between latitude $11^{0} 35^{\prime} 6^{\prime \prime} \mathrm{N}$ and longitude $7^{0} 14^{\prime} 28^{\prime \prime} \mathrm{E}$ of the reservoir from head water as adopted from Moshood (2008), Olaniyi (2013) and Tessema et al. (2014). The second Sampling Point (SPII) was selected from the middle between latitude $11^{0} 35^{\prime} 8^{\prime \prime} \mathrm{N}$ and longitude $7^{0} 14^{\prime} 41^{\prime \prime} \mathrm{E}$ of the reservoir and the third Sampling Point (SPIII) was selected from downstream (or outlet) between latitude $11^{0} 35^{\prime} 12^{\prime \prime} \mathrm{N}$ and longitude $7^{0} 14^{\prime} 15^{\prime \prime} \mathrm{E}$ of the reservoir as adopted from Tasi'u and Dabo (2017). The fourth Sampling Point (SPIV) was selected from the middle towards east, between latitude $11^{\circ} 35^{\prime} 39^{\prime \prime} \mathrm{N}$ and longitude $7^{\circ} 14^{\prime} 44^{\prime \prime} \mathrm{E}$ of the reservoir and the fifth Sampling Points was selected from the middle towards west, between latitude $11^{0} 35^{\prime} \mathrm{O}^{\prime \prime} \mathrm{N}$ and longitude $7^{0} 14^{\prime} 38^{\prime \prime} \mathrm{E}$ of the reservoir with an interval of $220 \mathrm{~m}$ between SPI, SPII and SPIII, $55 \mathrm{~m}$ between SPIV, SPII and SPV. In order to map out the sampling points using ArcGIS 10.3, the coordinate of each sampling point was taken using the Global Positioning System (GPS).

\section{Samples Collection}

To ensure quality control, clean bottles were used for sample collection. Samples were carefully collected by wading into the reservoir to avoid stirring up the water. Sample bottles were lowered carefully to receive undisturbed water. Touching the lip of the sample bottles and the cap was avoided as much as possible.

\section{Laboratory Techniques}

Later, the samples were taken to the Soil and Water Laboratory, Department of Geography, Umaru Musa Yar'adua University, Katsina State, for samples digestion in preparation for the Atomic Absorption Spectrum (A.A.S). The water sample was shaken very well before $100 \mathrm{ml}$ of it was collected into a measuring cylinder and the beaker labeled. To each, $3 \mathrm{ml}$ of concentrated Hydrochloric acid and $5 \mathrm{ml}$ of concentrated Nitric acid were measured and injected into the beaker containing the water samples to separate the metals present in the water sample. 
BAJOPAS Volume 14 Number 1,June, 2021

The mixture was placed on a hot plate and allowed to heat till $70 \mathrm{ml}$ of water vapor was obtained. Before the commencement of the A.A.S. analysis, the samples were stored in a refrigerator for a short period of time to minimalize chemical changes. The digested samples stored in the sample bottles were taken to the A.A.S. Laboratory, Faculty Agriculture, New Campus, Bayero University, Kano, for Spectrophotometric Analysis using the Atomic Absorption Spectrum (A.A.S), model: Agilent Technologies 200 Series AA. All the samples were allowed to stay until they reached room temperature before the analysis (StavrescuBedivan et al., 2015).

\section{Statistical Analysis}

The data was analyzed using the SPSS statistical package version 20.0. One-way ANOVA was used to test the spatial differences between the concentration levels of heavy metals across the reservoir. Independent $t$-test was used to test the temporal variations of heavy metal concentrations in dry and wet seasons in the reservoir as adopted from Karmakar et al (2011), Oyhakilome et al (2012) and Olaniyi
(2013). The findings of heavy metals were compared with the FAO standard of Water Quality Criteria for fishing.

\section{RESULTS AND DISCUSSION}

Chemical analysis of the presence of heavy metals in the water reservoir was carried out. The metals analysed included zinc (Zn), iron $(\mathrm{Fe})$, nickel $(\mathrm{Ni})$, manganese $(\mathrm{Mn})$, cadmium $(\mathrm{Cd})$ and lead $(\mathrm{Pb})$. The laboratory analysis was conducted seasonally between dry and wet seasons and spatially across the collection points (SPI, SPII, SPIII, SPIV and SPV) of the reservoir as well as an examination of the levels of heavy metal concentrations of the reservoir in relation to the FAO (2006) standards of water quality for fishing.

Comparing Heavy Metals Concentration of the Reservoir with FAO Standards for Fishing

Mean of each selected heavy metal analyzed was related to standard in order to contributes some knowledge about the status of the reservoir base on fishing purposes (Table 1).

Table 1: Comparing Heavy Metals Concentration of the Reservoir with FAO Standards for Fishing

\begin{tabular}{lllllll}
\hline \multirow{2}{*}{ Sampling points } & \multicolumn{5}{c}{ Heavy metal Concentrations } \\
\cline { 2 - 7 } & Fe (mg/l) & Cd $(\mathbf{m g} / \mathbf{I})$ & $\mathbf{Z n}(\mathbf{m g} / \mathbf{I})$ & $\mathbf{M n}$ & $\mathbf{P b}(\mathbf{m g} / \mathbf{I})$ & $\mathbf{N i}(\mathbf{m g} / \mathbf{I})$ \\
SPIMean & & & & $\mathbf{m g} / \mathbf{l})$ & & \\
SPIIMean & $0.28 \pm 0.01$ & $0.02 \pm 0.00$ & $0.06 \pm 0.04$ & $0.25 \pm 0.24$ & $0.29 \pm 0.18$ & $0.01 \pm 0.00$ \\
SPIII mean & $0.29 \pm 0.06$ & $0.03 \pm 0.00$ & $0.04 \pm 0.02$ & $0.03 \pm 0.02$ & $0.25 \pm 0.17$ & $0.03 \pm 0.01$ \\
SPIV mean & $0.35 \pm 0.06$ & $0.02 \pm 0.01$ & $0.11 \pm 0.11$ & $0.03 \pm 0.02$ & $0.38 \pm 0.29$ & $0.03 \pm 0.02$ \\
SPV mean & $0.26 \pm 0.13$ & $0.02 \pm 0.00$ & $0.04 \pm 0.03$ & $0.06 \pm 0.07$ & $0.31 \pm 0.35$ & $0.04 \pm 0.02$ \\
\hline Overall mean & $0.30 \pm 0.07$ & $0.02 \pm 0.00$ & $0.06 \pm 0.06$ & $0.10 \pm 0.15$ & $0.32 \pm 0.24$ & $0.03 \pm 0.02$ \\
\hline $\begin{array}{l}\text { FAO (2006) } \\
\text { standards }\end{array}$ & $\leq 0.300$ & $\leq 0.003$ & $\leq 3.000$ & $\leq 0.400$ & $\leq 0.100$ & $\leq 0.200$ \\
\hline
\end{tabular}

Keys: SP - Sampling points: SPI (upstream), SPII (middle), SPIII (downstream), SPIV (middle towards east) and SPV (middle towards west). FAO - Food and Agricultural Organization (2006).

The results of this study show that with the exception of cadmium (Cd) and lead $(\mathrm{Pb})$, the heavy metal concentrations in water did not exceed FAO (2006) standards(Table 1). Low concentration of metals in the reservoir may be attributed to the increased cover of the aquatic and higher plants, which absorbs metals from water and sediments. However, $\mathrm{Cd}$ and $\mathrm{Pb}$ exceeded the FAO (2006) standard. Therefore, based on these heavy metal concentrations, the reservoir needs to be treated for safer fishing. Similar findings with regard to $\mathrm{Pb}$ and $\mathrm{Cd}$ concentrations were reported by Abdullahi et al. (2013) on the industrial waste water of Riyadh city, Saudi Arabia, pointing to untreated industrial effluents as other source of heavy metals in the environment. Heavy metals, such as $\mathrm{Cr}, \mathrm{Pb}, \mathrm{Cd}$, are not destroyed by incineration, rather they become volatile at high temperatures (Min-Hao and LinWun-Yue, 2014).Airborne sources of heavy metals include aerial emission from combustions (Wuana and Okieimen, 2011). Combustions of coal and other fossil fuels are important sources of heavy metal emissions to the atmosphere. When in complexes with these metals, the biological molecules lose their ability to function properly and result in the malfunction/death of affected cell (Adata et al. 2015).

According to EPA (2015), a high concentration of lead in the aquatic food chain causes a grave danger to both humans, as consumers, and aquatic animals. The acute intoxication of fish with lead can be recognized by damaged gills 
BAJOPAS Volume 14 Number 1,June, 2021 epithelium, erythrocytes, leucocytes and the nervous system. In addition, lead can delay embryonic development, suppress reproduction and inhibit growth, increase mucus formation, neurological problem, enzyme inhalation and kidney dysfunction (Kori-Siakpere and Ubogu, 2008). Cadmium toxicity in natural water arising from pollutants may cause severe damage in gills and necrotic changes in the liver and kidneys. Cadmium is related to cancer, skin damage, kidney damage and heart disease (QA and MS, 2016).

Seasonal Variation in Heavy Metals Concentrations of Mairua Reservoir

Laboratory analysis was conducted seasonally between dry and wet seasons with a view to contribute some knowledge about the effect of seasons on selected heavy metal concentration of the reservoir

Table 2: Seasonal Variation in Heavy Metals Concentrations of Mairua Reservoir

\begin{tabular}{|c|c|c|c|c|c|c|}
\hline \multirow{2}{*}{ Seasons } & \multicolumn{2}{|c|}{ Heavy metal concentrations } & \multirow[b]{2}{*}{$\mathrm{Zn}(\mathrm{mg} / \mathrm{l})$} & \multirow[b]{2}{*}{$\mathrm{Mn}(\mathrm{mg} / \mathrm{l})$} & \multirow[b]{2}{*}{$\mathrm{Pb}(\mathrm{mg} / \mathrm{l})$} & \multirow[b]{2}{*}{$\mathrm{Ni}(\mathrm{mg} / \mathrm{l})$} \\
\hline & $\mathrm{Fe}(\mathrm{mg} / \mathrm{l})$ & $\mathrm{Cd}(\mathrm{mg} / \mathrm{l})$ & & & & \\
\hline Dry & $0.27 \pm 0.07$ & $0.02 \pm 0.00$ & $0.05 \pm 0.04$ & $0.10 \pm 0.15$ & $0.41 \pm 0.30^{a}$ & $0.03 \pm 0.02$ \\
\hline Wet & $0.32 \pm 0.07$ & $0.02 \pm 0.00$ & $0.06 \pm 0.07$ & $0.10 \pm 0.15$ & $0.24 \pm 0.13^{b}$ & $0.03 \pm 0.02$ \\
\hline Mean value & $0.19 \pm 0.07$ & $0.02 \pm 0.00$ & $0.06 \pm 0.06$ & $0.10 \pm 0.15$ & $0.32 \pm 0.24$ & $0.03 \pm 0.02$ \\
\hline$p$-value & 0.106 & 0.614 & 0.700 & 0.950 & 0.047 & 0.937 \\
\hline
\end{tabular}

The levels of parameters were compared based on seasons (wet and dry) using independent ttest at the 0.05 level of significance. The result shows no significant difference at the 0.05 level between wet and dry season values of $\mathrm{Fe}(P$ value 0.106$), C d$ ( $P$ value 0.614$), Z n$ ( $P$ value $0.700), \mathrm{Mn}(P$ value 0.950$)$ and $\mathrm{Ni}(P$ value 0.937).Study of $\mathrm{Pb}$ concentrations revealed that the metal was affected by seasonal variation ( $P$ value 0.047 ) (Table 2 ). This result corresponds with the work of Olaniyi (2013), which reported no significant difference among the value of $\mathrm{Fe}$, but contrary in terms of $\mathrm{Pb}$ concentrations, which shows no significant difference in the water samples of Abekuta North. This finding is also contrary to that of Tasi'u and Dabo (2017), which reported Ni significant at 0.05 in the water samples of Safke Reservoir, Daura, Nigeria and that of Tessema et al. (2014) where Fe and Mn are significant in Awash River, Ethopia. But both
Tasi'u and Dabo (2017) \& Tessema et al. (2014) reported $\mathrm{Pb}$ significance which corresponds to the current study. The study shows that the order of the occurrence of heavy metals in the reservoir during the dry season was: $\mathrm{Pb}>\mathrm{Fe}>$ $\mathrm{Mn}>\mathrm{Zn}>\mathrm{Ni}>\mathrm{Cd}$. However, during the wet season, the order of occurrence of heavy metals was: $\mathrm{Fe}>\mathrm{Pb}>\mathrm{Mn}>\mathrm{Zn}>\mathrm{Ni}>\mathrm{Cd}$. These findings are similar with those reported by AlAfify et al. (2010). This shows that the two reservoirs sheared some common environmental factors together.

Variation in Heavy Metals Concentrations across the Sampling Points

Study on selected heavy metal concentrations was spatially across the collection points (SPI, SPII, SPIII, SPIV and SPV)in the reservoir with the view to contribute some knowledge about the effect of spatial locations of the reservoir on selected heavy metal concentrations (Table 3).

Table 3: Variation in Heavy Metals Concentration across the Sampling Points

\begin{tabular}{lllllll}
\hline \multirow{2}{*}{ Sampling points } & \multicolumn{5}{c}{ Heavy metal Concentrations } \\
\cline { 2 - 7 } & Fe (mg/l) & $\mathbf{C d}(\mathbf{m g} / \mathbf{I})$ & $\mathbf{Z n}(\mathbf{m g} / \mathbf{I})$ & $\mathbf{M n}$ & $\mathbf{P b}(\mathbf{m g} / \mathbf{I})$ & $\mathbf{N i}(\mathbf{m g} / \mathbf{I})$ \\
SPI Mean & $0.28 \pm 0.01$ & $0.02 \pm 0.00$ & $0.06 \pm 0.04$ & $0.25 \pm 0.24$ & $0.29 \pm 0.18$ & $0.01 \pm 0.00$ \\
SPII Mean & $0.30 \pm 0.07$ & $0.03 \pm 0.00$ & $0.04 \pm 0.02$ & $0.03 \pm 0.02$ & $0.25 \pm 0.17$ & $0.03 \pm 0.01$ \\
SPIII mean & $0.29 \pm 0.06$ & $0.03 \pm 0.00$ & $0.11 \pm 0.11$ & $0.03 \pm 0.02$ & $0.38 \pm 0.29$ & $0.03 \pm 0.02$ \\
SPIV mean & $0.35 \pm 0.06$ & $0.02 \pm 0.01$ & $0.04 \pm 0.03$ & $0.06 \pm 0.07$ & $0.31 \pm 0.35$ & $0.04 \pm 0.02$ \\
SPV mean & $0.26 \pm 0.13$ & $0.02 \pm 0.00$ & $0.04 \pm 0.02$ & $0.13 \pm 0.13$ & $0.38 \pm 0.23$ & $0.04 \pm 0.02$ \\
\hline Overall mean & $0.30 \pm 0.07$ & $0.02 \pm 0.00$ & $0.06 \pm 0.06$ & $0.10 \pm 0.15$ & $0.32 \pm 0.24$ & $0.03 \pm 0.02$ \\
\hline P- value & 0.018 & 0.615 & 0.175 & 0.032 & 0.865 & 0.011 \\
\hline
\end{tabular}

Keys: SP - Sampling points: SPI (upstream), SPII (middle), SPIII (downstream), SPIV (middle towards east) and SPV (middle towards west). 
BAJOPAS Volume 14 Number 1,June, 2021

The result shows that the mean value of $\mathrm{Fe}$ is highest at SPIV with $0.35 \mathrm{mgL}^{-1}$ and the overall mean $\mathrm{Fe}$ is $0.19 \mathrm{mgL}^{-1}$. The mean $\mathrm{Cd}$ is highest at SPII and SPIII with $0.03 \mathrm{mgL}^{-1}$, respectively. The overall mean is $0.02 \mathrm{mgL}^{-1}$. $\mathrm{Zn}$ concentration of the reservoir ranged between $0.11 \mathrm{mgL}^{-1}$ at SPIII to $0.04 \mathrm{mgL}^{-1}$ at SPII and SPV respectively, with the overall mean of $0.06 \mathrm{mgL}^{-1}$.The $\mathrm{Mn}$ concentration mean value ranged between is $0.03 \mathrm{mgL}^{-1}$ at SPI to $0.25 \mathrm{mgL}^{-1}$ at SPII and SPIII respectively, with an overall mean of $0.10 \mathrm{mgL}^{-1}$. The mean value of the $\mathrm{Pb}$ concentration of the reservoir ranged between $0.38 \mathrm{mgL}^{-1}$ at SPIII and SPV to $0.25 \mathrm{mgL}^{-1}$ at SPII with overall mean of $0.32 \mathrm{mgL}^{-1}$. The mean value of the $\mathrm{Ni}$ concentration of the reservoir ranged between $0.04 \mathrm{mgL}^{-1}$ at SPIV and SPV to0.01 $\mathrm{mgL}^{-1}$ at SPI with an overall mean of $0.03 \mathrm{mgL}^{-1}$. The mean value of most of the parameters are highest at SPIII (Table 3), which is linked to other anthropogenic practices, especially household materials that were deposited more in the lower region of the reservoir is close to semi-urban settlements. The finding is contrary to that of Tasi'u and Dabo (2017), which reported that most of the parameters were more concentrated at the entrance (SPI) of the reservoir. Furthermore, the analysis of variance revealed no significant difference $(p>0.05)$ in the values of all the heavy metal concentrations across the sampling points. This indicates that these heavy

\section{REFERENCES}

Abdullahi S.A., Mohammad, A., Anwar A. Mohammed A. and Sallem E. (2013). Assessment and heavy metal behaviors of industrial waste: A case study of Riyadh city, Saudi Arabia. Proceedings of the international academy and ecology and environmental sciences. 3 (3): 266277.

Adata, A. J., Wegwu, M. O., Belonwu, D. C. and Okerenta, B.M. (2015). Assessment of Heavy Metals Concentrations of Selected Fin and Shell Fish from Ogoniland. Journal of Environment and Earth Science. 5 (18): 15-19.

AGU special report (1995), Chapman Conference Probes Water Vapour in the Climate System. EOS. 4: 67-71.

Al-Afify, A. D. G., Osman, M. A., Mohamed, M. A. M. and Ali, M. H. H. (2010). Assessment of Agriculture Drainage Water Quality to be used for Fish Farm Irrigation. Nature and Science, $8(8), 60$ 71.

Armah, F.A., Obiri, S., Yawson, D.O., Pappoe, A.N.M., and Akoto, B. (2010), Mining and Heavy Metals Pollution; Assessment metal concentrations did not vary spatially in the reservoir. This result corresponds with the work of Ogunleye and Izungie (2013) of no significant difference among the values of the heavy metal concentrations across the sampled collections and also contradicts that of Butu and Iguisi (2013), which reported spatial variation in the concentration of some selected heavy metals in Galma Dam, Zaria

\section{CONCLUSION}

Findings show that most of the heavy metals like $\mathrm{Cd}, \mathrm{Zn}$ and $\mathrm{Pb}$ are more in concentration at SPIII (downstream),i.e. the outlet of the water in the reservoir. This is due to the dumping site located much closer to the outlet of the reservoir. It can also be seen that two heavy metals, $\mathrm{Fe}$ and $\mathrm{Ni}$, are more concentrated at SPIV (middle towards east) and only $\mathrm{Mn}$ is higher at SPI (upstream). Furthermore, the analysis of variance revealed no significant difference $((p>0.05)$ in the values of all the heavy metal concentrations across the sampling points. The results of this study show that with the exception of cadmium (Cd) and lead $(\mathrm{Pb})$, the heavy metal concentrations in water did not exceed FAO (2006) standards. However, $\mathrm{Cd}$ and $\mathrm{Pb}$ exceeded the standards. Therefore, based on these heavy metal concentrations, the reservoir needs to be treated for safer fish productions.

of Aquatic Environment in Tanwa (Ghana), using Multivariate Statistical Analysis. Journal of Environmental Statistics 1 (4) 1-12.

Babsal, O. (1998). Katsina State in focus. Macmillian Pulishers, Kano.

Butu A.W and Iguisi E.G. (2013). Concentration of heavy metals in sediment of river Kubanni, Zaria, Nigeria. Comprehensive Journal of Environment and Earth Sciences, 2(1): 10-17.

Dabo, Z.M. (2020). Assessment of Water Quality for Fishing in the Mairua Reservoir, Funtua,, Katsina State, Nigeria. M.Sc. (Environmental Management), Bayero University, Kano. Page 64

EPA (2015). Ecological Risk Assessment. (https://www.epa.gov/risk/ecologicalrisk-assessiment)

FAO (Food and Agriculture Organization of the United Nations) (2006). State of World Aquaculture. 2006. FAO Fisheries Technical paper 500. Rome: FAO Fisheries Department.

Karmakar, S., Surajul, S.M., Mozaffar, M. H. and Shafiq (2011) Water Quality of Kaptai 
BAJOPAS Volume 14 Number 1,June, 2021 Reservoir in Chittagong Hill Tracks of Bangladesh. Journal of Forestry Research Springer Link 22(1) 87-92.

Katsina Wikipedia (2003) Katsina State Physical Setting, people population and settlement posted on 30/1/2003.

Kori-siakpere, O. and Ubogu, E. O. (2008). Sublethal haematological effects of zinc on the freshwater fish, Heteroclarias sp. (Osteichthyes: Clariidae). African Journal of Biotechnology, 7(12): $2068-2073$.

Lye, E., Legrand, M., Clarke, J., and Probert, A. (2013). Canadian Health Measures Survey Cycle 1, 2007-2009. Canadian Journal of Public Heath 104(3): 246-251

Min-Hao, W., and LinWun-Yue, Z. (2014). Effect of Waste Incineration and Gasification Processes on Heavy Metal Distribution. Fuel Processing Technology. 125(1): 6772.

Moshood, M.K. (2008) Assessment of water quality of Oyun reservoir, offa, Nigeria using selected physicochemical parameters. Turkish Journal of Fisheries and Aquatic Sciences 8(1) 309-319.

National Population Commission, Census (2006). Federal Republic of Nigeria

Nsi, E.W (2007). Basic Environmental Chemistry. Makkurdi Nigeria: The Return Press Ltd: 128.

Obadaki, Y.Y. and Ari A.A. (2014). The doma dam and its socio-economic implication in doma local government area of Nasarawa state. International Journal of Humanities, Arts. Medicine and Sciences, 2(4):87-98.

Ogunleye, I. O., and Izungie, A. A. (2013). Determination of heavy metal contents in some industrial effluents from Ondo State, Nigeria. Journal of Environmental Chemistry und Ecotoxicology 5(8): 216219

Olaniyi, O. (2013) Assessment of Water Quality Chracteristics for Aquaculture uses in Abekuta North L.G.A, Ogun state, Nigeria. Journal of Lakes reservoirs and Ponds of Romanian Limnogeopolitical Association 7(1) 9-192013.

Onamade, A. (2014). Access and Utilization of Antenatal Care Services in Funtua Local Government Area, Katsina State, Nigeria. M.Sc. (Geography), Ahmadu Bello University, Zaria. P58.

Oyhakilome, G.I., Aiyesanmi, A.F. and Akharaiyi, F.C (2012) Water Quality Assessment of the Owena multi-purpose Dam, Ondo State, Southwestern Nigeria. Journal of Environmental Protection 3(5) 14-25.

QA, M., and MS, K. (2016). Effect on Human Health due to Drinking Water Contaminated with Heavy Metals. J. Pollut. Eff. Control 05, 10-11.

Saei-Dehkordi, S.S. and Fallah, A.A. (2011). Determination of Copper, Lead, Cadmium and Zinc Content in Commercially Valuable Fish Species from the Persian Gulf using Potentiometric Stripping Analysis. Microchemical Journal 98(1): 156-162.

Sen, I., Shandil, A. and Shrivastava, V. S. (2011). Study for Determination of Heavy Metals in Fish Species of the River Yamuna (Delhi) By Inductively Coupled Plasma-Optical Emission Spectroscopy (I CP-OES) Advances in Applied Scientific Research, 2(2):161166.

Stavrescu-Bedivan, M., Scaeteanu, G.V., Madjar, R.M., Manole, M.S., Staicu, A.C., Aioanei, E.F.P., Toba, G.L. and Nicolae, C.G. (2016). Interactions between fish well-being and water quality: a case study from MoriiLake area, Romania. Agriculture and Agricultural Science Procedia, 10:328-339.

Tanee, T., Chaveerach, A., Narong, C., Pimjai, M., Punsombut, P. and Sudmoon, R. (2013). Bioaccumulation of Heavy Metals in Fish from the Chi River, Maha Sarakham Province, Thailand. International Journal of Biosciences. 3(8): 159-167.

Tasi'u Y.R and Dabo Z.M.(2017). Water Quality Assessment for Fishing, In Safke Reservoir, Dannakola Daura, Katsina State Nigeria. Journal of Arid Zone Economiy 12 (4) 126 - 138.

Tessema, A., Mohammed, A., Bihanu, T., and Negu, T. (2014) Assessment of Physico-chemical Water Quality of Bira Dam, Bati Warade, Amhara Region Ethiopia. Journal of Agriculture Research and Development 5(267) 2155-9546.

World Health Organization (WHO) (2011). World press reveals 2011. P25

Wuana, R.A., and Okieimen, F.E. (2011). Heavy Metals in Contaminated Soils: A Review of Sources, Chemistry, Risks and Best Available Strategies for Remediation. Ecology 11:1-20. 